\title{
Testing Vaginal Irritation with the Hen's Egg Test-Chorioallantoic Membrane Assay
}

\author{
Rita Palmeira-de-Oliveira 1,2,3, Rita Monteiro Machado 1,2, José Martinez-de-Oliveira 1,4 and \\ Ana Palmeira-de-Oliveira 1,2 \\ ${ }^{1}$ CICS, UBI - Health Sciences Research Center, Faculty of Health Sciences, University of Beira Interior, Covilhã, Portugal; ${ }^{2}$ Labfit, HPRD - Health \\ Products Research and Development, Lda, Edifício UBIMEDICAL, Covilhã, Portugal; ${ }^{3}$ Center for Neuroscience and Cell Biology, University of Coimbra, \\ Rua Larga, Coimbra, Portugal; ${ }^{4}$ Child and Woman's Health Department, Centro Hospitalar Cova da Beira EPE, Covilhã, Portugal
}

\begin{abstract}
The HET-CAM (Hen's Egg Test-Chorioallantoic Membrane) assay is an in vitro alternative to the in vivo Draize rabbit eye test. This qualitative method assesses the irritancy potential of chemicals. The chorioallantoic membrane responds to injury with an inflammatory process similar to that in the rabbit eye's conjunctival tissue. Regarding topical toxicity assessment of medical devices, ISO 10993-10 states that any skin or eye irritant material shall be directly labelled as a potential vaginal irritant without animal testing, suggesting that the irritation potentials for the eye and the vaginal epithelia are similar. The aim of this work was to apply the HET-CAM assay to test the irritancy potential of vaginal formulations. Vaginal semisolid medicines and lubricants currently marketed were tested along with the Universal Placebo formulation that has been shown to be clinically safe. Nonoxynol-9 (N-9), a known vaginal irritant, was enrolled as positive control (concentrations ranging from 0.001 to $100 \%(\mathrm{v} / \mathrm{v})$ ). The assay was conducted according to the ICCVAM - Recommended Test Method (NIH Publication No. 10-7553 - 2010). Formulations were then classified according to irritation score (IS), using the analysis methods (A) and (B). The studied vaginal formulations showed low potential for irritation. N-9 was classified as a severe irritant at concentrations above $2 \%$, which is in line with clinical data, envisaging a possible in vitro/in vivo correlation. IS (B) was considered a more detailed classification output. Although still requiring further validation, the HET-CAM assay seems an ideal prospect for in vitro vaginal irritancy testing.
\end{abstract}

\section{Introduction}

Topical toxicity has been a main topic of work within the European Union Reference Laboratory for Alternatives to Animal Testing (EURL-ECVAM). Having also a regulatory responsibility, the EU and associated laboratories have been working on developing and validating toxicity test methods for eye irritation, phototoxicity, skin corrosion, irritation and sensitization. Furthermore, several in vitro Test Guidelines are already accepted or being developed by the Organisation for Economic Co-operation and Development (OECD). Further in vitro studies have been validated and recommended as a first screening for toxicity evaluation. The European Commission has undertaken several regulatory decisions in pursuance of the 3Rs policy (Replacement, Reduction, Refinement) such as the approval of the REACH (Registration, Evaluation and Authorization of Chemicals) legislation (applicable to the fields of raw materials, drug products and medical devices, for example) and the prohibition of the marketing of cosmetic products tested in animals (EC, 2003).

Since vaginal products are mostly intended for self-administration and aim to offer maximum comfort both at the moment of application and during the time of use, the evaluation of adverse effects such as local irritation is especially important. One of the methods most used to assess vaginal irritation is performed in vivo on rabbits (RVI) (OECD, 2012; Eckstein et al., 1969). The assessment of the irritancy and toxicity of products for vaginal administration does not yet include validated in vitro methods. Currently, numerous medicines and medical devices are marketed or under development for vaginal administration (Woolfson et al., 2000; Alexander et al., 2004; Hussain and Ahsan, 2005; Choudhury et al., 2011). Regarding topical toxicity assessment of medical devices, the ISO 10993-10 states that any skin or eye irritant material shall be directly labelled as a potential vaginal irritant without animal testing, suggesting that the irritation po- 
tentials for the eye and the vaginal epithelia are similar (ISO 10993-10, 2010). Although various non-animal techniques for the characterization of vaginal formulations have been described in the literature (Garg et al., 2001, 2010; Adriaens and Remon, 2008; Cunha et al., 2014), most have been applied only to developing formulations, without correlations with in vivo results having been performed.

The Hen's Egg Test, or Hühner-Embryonen-Test (HET), first reported by Luepke (1985), was developed as a rapid, sensitive and inexpensive toxicity test able to provide information on embryotoxicity, teratogenicity, systemic, metabolic, and immunopathological effects. The method was designed to be applied in mucous membrane irritation testing, and the analysis method developed for scoring and classification was analogous to the in vivo Draize rabbit eye test. In the 1990's, Spielmann and Steiling contributed to broaden the application of this method by adapting it to classify eye irritants. The procedure was published as INVITTOX protocol number 47 (Spielmann, 1992; Steiling et al., 1999) and is one of the alternatives supported by EURL-ECVAM ${ }^{1}$ for the in vitro study of ocular irritancy (ICCVAM, 2007) that is already widely applied to ocular products (Fernández-Ferreiro et al., 2014).

The HET-CAM assay has also been applied in other settings (for review see Vargas et al., 2007), e.g., to test dental restorative materials and dental adhesive agents (Lönnroth, 1999; Dahl, 2007), as an angiogenesis model for tissue engineering (Borges et al., 2003), to test the anti-inflammatory effect of plasma to treat chronic skin wounds (Bender et al., 2011), to evaluate the irritation potential of topical antiseptics (Marquardt et al., 2010) and to determine the irritation potential of vaccine adjuvants for nasal and subcutaneous administration (Batista-Duharte et al., 2016). The test consists in controlled incubation, for 9 days, of White Leghorn chicken eggs followed by application of the test substance on the surface of the CAM and observation of changes in the vessels.

Although using incubated hen's eggs for tests could represent a borderline case between in vivo and in vitro systems, it does not conflict with ethical and legal obligations, especially animal protection laws. It was demonstrated that for incubation up to day nine, the embryonic differentiation of the chicken's central nervous system is sufficiently incomplete to lack suffering and pain perception. The few sensory fibers present at day nine only become functional at days 11 to 14 (Liebsch et al., 2011). Also, the extra-embryonal vascular systems (e.g., yolk sac, CAM) are not sensitive to pain (Spielmann, 1995). Therefore, this test method can already reduce the number of animals subjected to testing and reduce the pain and suffering of rabbits by their exclusion from the testing of corrosives and severe irritants (U.S. Public Health Service, Department of Health and Human Services (2006)).

The HET-CAM's possible application for the testing of vaginal formulations is an innovative proposal. The HET-CAM assay outcome consists of a calculated Irritation Score (IS) that takes into account the scoring of three endpoints after application of the test substance. Two methods are in use to calculate the IS. For IS (A), endpoints are scored at $0.5,2$, and 5 min post exposure and the scores are computed to yield an overall irritation score. For IS (B), the endpoints are monitored over the entire observation period after applying the test substance (typically $5 \mathrm{~min}$ ). The time (in seconds) when an endpoint starts to develop is registered and this value is converted to a score (U.S. Public Health Service, Department of Health and Human Services, 2006).

The aim of this study was to evaluate the possibility of using the HET-CAM assay as an in vitro alternative method to the in vivo vaginal irritation test in rabbits. Vaginal semisolid medicines and lubricants were examined for their irritation potential using two scoring methods, IS (A) and IS (B). Nonoxynol-9, a well-known vaginal irritant (0.001 to $100 \%$ (v/v)) and Universal Placebo formulation were studied as positive and negative controls, respectively.

\section{Materials and methods}

\subsection{Chemicals and testing products}

For the preparation of the assay controls, the following chemicals were used: sodium chloride ( $\mathrm{NaCl}$, JT Baker, USA), sodium dodecyl sulphate (SDS, Acros Organics, Belgium), nonoxynol-9/ tergitol (N-9, Sigma, Germany), sodium hydroxide ( $\mathrm{NaOH}, \mathrm{VWR}$ Prolabo, Germany) and type I water (obtained in-house through a Millipore System, Merck, USA).

The products included in this study were commercial vaginal semisolids intended either as therapeutics for different pathological conditions (drug products) or as lubricants for sexual or menopausal discomfort.

The ten therapeutic products were: Gino-Canesten ${ }^{\circledR}$ (Bayer), Sertopic ${ }^{\circledR}$ (Ferrer), Dermofix ${ }^{\circledR}$ (Azevedos Laboratories), Gynopevary $l^{\circledR}$ (Johnson \& Johnson), Lomexin ${ }^{\circledR}$ (Jaba Recordati), Gino Travogen $^{\circledR}$ (Bayer), Dalacin $V^{\circledR}$ (Pfizer Laboratories), Ovestin ${ }^{\circledR}$ (Aspen Pharma), Blissel ${ }^{\circledR}$ (ITF Medivida), Colpotrophine ${ }^{\circledR}$ (Teva Pharma).

The lubricants tested were: Fillergyn ${ }^{\circledR}$ gel (BSDpharma), Geliofil ${ }^{\circledR}$ Classic gel (Laboratoires Effik), GelSea ${ }^{\circledR}$ gel (LDPSA), Ginix ${ }^{\circledR}$ gel (ISUS), Ginix ${ }^{\circledR}$ Plus gel (ISUS), Hyalo Gyn ${ }^{\circledR}$ gel (Fidia Farmaceutici), K-Y ${ }^{\circledR}$ Jelly (Johnson \& Johnson), Phyto Soya ${ }^{\circledR}$ gel (Arkopharma Laboratoires Pharmaceutiques), Velastisa ${ }^{\circledR}$ Intim VG moisturizer gel cream (ISDIN), and Vidermina ${ }^{\circledR}$ gel (Istituto Ganassini).

Both Replens ${ }^{\circledR}$ (Laboratoires Majorelle) and Universal Placebo (Tien et al., 2005) were used as controls, since their low toxicity profiles are largely described on the literature (Nachtigall, 1994; Bygdeman and Swahn, 1996; Tien et al., 2005; Valenta, 2005; Schwartz et al., 2007; Adriaens and Remon, 2008; Acartürk, 2009; Garg et al., 2010; Clark et al., 2011; Caramella et al., 2015). Universal Placebo was prepared by dissolving $2.7 \mathrm{~g}$ hydroxyethylcellulose $(2000 \mathrm{cP})$ in $96.3 \mathrm{~g}$ water containing $0.85 \mathrm{~g}$ sodium chloride and $0.1 \mathrm{~g}$ sorbic acid. The final $\mathrm{pH}$ was adjusted to 4.4 by adding sodium hydroxide, and the gel was stored at $2-8^{\circ} \mathrm{C}$.

To evaluate the method's sensitivity to vaginal irritants, nonoxynol-9 (N-9) was used in concentrations ranging from 0.001 to $100 \%(\mathrm{v} / \mathrm{v})$ (aqueous solutions, when applicable).

\footnotetext{
${ }^{1}$ https://eurl-ecvam.jrc.ec.europa.eu/validation-regulatory-acceptance/topical-toxicity/ (accessed 31.10.2016)
} 


\subsection{Eggs and incubation conditions}

The test system consists of fertile White Leghorn chicken eggs that are fresh (not more than 7 days old), clean and weigh 45 to $65 \mathrm{~g}$. Upon arrival at the lab, eggs were checked for damage to the shell and damaged eggs were discarded. Undamaged eggs were incubated at $37.8 \pm 0.3^{\circ} \mathrm{C}$ in a relative humidity of $58 \pm 2 \%$ and under automatic rotation for 8 days (Corti AF-50 and Copele 30652, Spain). On the eighth day, eggs were inspected using a LED light to confirm embryo formation. Non-embryonated and non-viable eggs were discarded. Eggs were incubated for one further day under the same conditions but without rotation.

\subsection{HET-CAM assay}

The assay was conducted according to the ICCVAM - Recommended Test Method (NIH Publication No. 10-7553 - 2010). At day 9, eggs were taken out of the incubator and placed on an appropriate support with the wider part facing up. The shell was opened using a scalpel and tweezers and the internal membrane was exposed. This membrane was then hydrated with $\mathrm{NaCl} 0.9 \%$ $(\mathrm{w} / \mathrm{v})$ for a maximum of $30 \mathrm{~min}$. The solution was aspirated and the membrane was peeled off without damaging the blood vessels. $0.3 \mathrm{ml}$ test product was applied to the chorioallantoic membrane (CAM). 3 eggs were used per product. All samples were semisolids, they were applied to cover around $50 \%$ of the CAM, as specified in the protocol. The irritant effect of each product was evaluated on the remaining part of the CAM (except for non-opaque formulations which allowed observation of the whole CAM), by monitoring three endpoints for $5 \mathrm{~min}$ : hemorrhage (vessel bleeding), lysis (vessels disintegration) and coagulation (intra and extra-vascular protein denaturation).

These endpoints were evaluated accordingly to two different analysis methods: Irritation score (IS) A and B. While for criteria A the endpoints were checked at predetermined time intervals $(0.5,2$, and $5 \mathrm{~min})$, for criteria B the effects were monitored continuously over $5 \mathrm{~min}$, and the time (in seconds) at which the irritant response started was registered. This methodological difference leads to two different ranges of categories in the outcome (see Tab. 1). Photographs were taken at the beginning and at the end of the assays. Calculation of the IS for each test product is represented as mean \pm standard deviation (SD) of a total of three eggs.

\section{Results}

The irritation potential determined for N-9 using the HETCAM assay using both evaluation methods, IS (A) and (B) was reasonably comparable (Fig. 1). Only at the concentration of $0.5 \%(\mathrm{v} / \mathrm{v})$ the difference between the two testing criteria results was statistically different (two way-ANOVA, $p<0.05$, Sidak's multiple comparisons test), although it must be noted that standard deviations were relatively high. This concentration seems to be the one that presents a borderline-type behavior (Leontaridou et al., 2017), since its score (on criteria B) is on the limit between slight and moderate irritant. The same might be happening for concentration $1 \%$, which is between the moderate and severe irritant categories on the IS (B) scale if score 9 is considered as the cut-off for the "severe irritant" classification, although it would fall within the moderate irritant classification (for cut-off 10 at IS(B)) and "non severe irritant" according to IS (A) classification. It also can be observed that concentrations above $2 \%$ correspond to IS values higher than 9 , meaning that at these concentrations N-9 exhibit a severe irritation effect (IS (A) ${ }_{\mathrm{N}-9} 2 \%=10.0 \pm 0$; IS (B) ${ }_{\mathrm{N}-9} 2 \%=10.8 \pm 0$ ). Taking into consideration the IS (B) criteria, concentrations between 0.3 and $1 \%$ were classified as slight and moderate irritants, respectively (IS (B) ${ }_{\mathrm{N}-9} 0.3 \%=4.8 \pm 0.5$; IS (B) $\mathrm{N}-91 \%=8.7 \pm 0.4$ ) and concentrations between 0.01 and $0.2 \%$ were slightly irritant (IS (B) $\mathrm{N}-90.01 \%=3.7 \pm 0.6$; IS (B) $\mathrm{N}-90.2 \%=4.9 \pm 0.7$ ). It should be noted that, considering the presented standard deviations for

Tab. 1: Irritancy classification

Classification of results of the in vitro HET-CAM assay using Irritation Score (IS) analysis methods A and B.

\begin{tabular}{|c|c|c|c|c|c|}
\hline & \multicolumn{4}{|c|}{ Analysis method A } & Analysis method B \\
\hline $\begin{array}{l}\text { Irritation } \\
\text { response }\end{array}$ & \multicolumn{4}{|c|}{$\begin{array}{l}0 \text { to } 9: \text { Non-severe irritant } \\
>9 \text { (to } 21 \text { ): Severe irritant }\end{array}$} & $\begin{array}{l}0 \text { to } 0.9 \text { : Non-irritant } \\
1 \text { to } 4.9 \text { : Slight irritant } \\
5 \text { to } 8.9^{*}: \text { Moderate irritant } \\
9 \text { to } 21^{*}: \text { Severe irritant }\end{array}$ \\
\hline \multirow[t]{6}{*}{$\begin{array}{l}\text { IS calculation } \\
\text { method }\end{array}$} & \multicolumn{4}{|c|}{$\begin{array}{l}\text { The IS is calculated as the sum of the scores attributed } \\
\text { at each time point to the arising of the corresponding } \\
\text { effect, as stated on the following scheme: }\end{array}$} & \multirow{5}{*}{$\begin{array}{l}\text { Calculation of the IS by applying the following equation: } \\
\qquad \begin{array}{r}{\left[\left(\frac{(301-\text { Hemorrhage time })}{300}\right) \times 5\right]} \\
+\left[\left(\frac{(301-\text { Lysis time })}{300}\right) \times 7\right] \\
+\left[\left(\frac{(301-\text { Coagulation time })}{300}\right) \times 9\right]\end{array}\end{array}$} \\
\hline & \multirow[t]{2}{*}{ Endpoint } & \multicolumn{3}{|l|}{ Score } & \\
\hline & & $0.5 \min$ & $2 \mathrm{~min}$ & $5 \min$ & \\
\hline & Lysis & 5 & 3 & 1 & \\
\hline & Hemorrhage & 7 & 5 & 3 & \\
\hline & Coagulation & 9 & 7 & 5 & $\begin{array}{l}\text { Times should be replaced by the time (in seconds) at } \\
\text { which each effect started. }\end{array}$ \\
\hline
\end{tabular}

*Note: The cut-off for "severe irritant" is also presented in the literature as 10 (“5-9.9: Moderate irritant; 10-21: Severe irritant") (US Public Health Service 2006). 


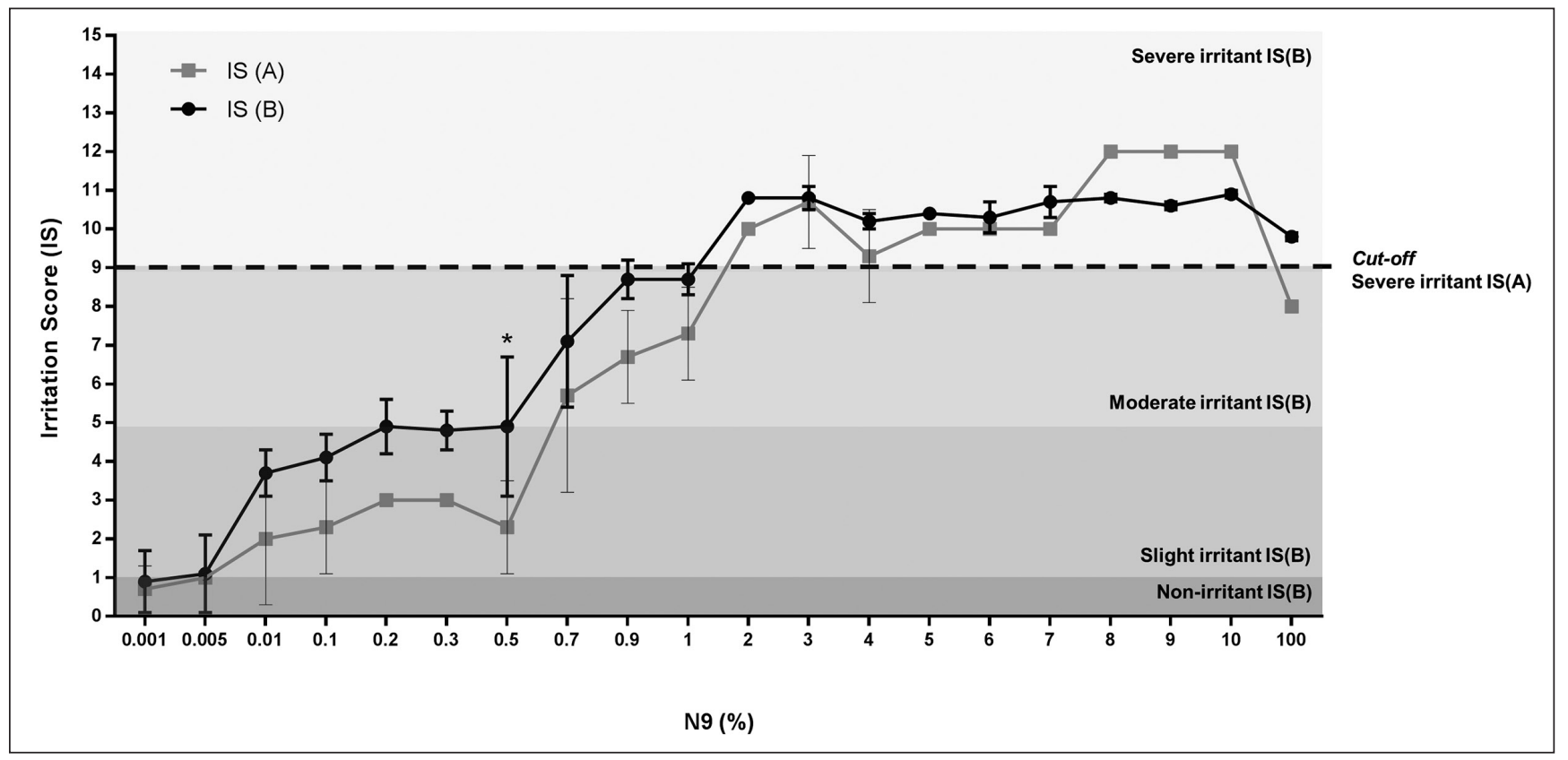

Fig. 1: Irritation scores (IS) for N-9 (nonoxynol-9) according to the analysis methods $A$ and $B$

Results are presented as mean values \pm standard deviation (SD), $n=3 .{ }^{*}, p<0.05$ (two way-ANOVA, Sidak's multiple comparisons test). "Severe irritants" are identified by score $>9$ (IS A) and $>9$ or $>10$ (different references) according to IS B.

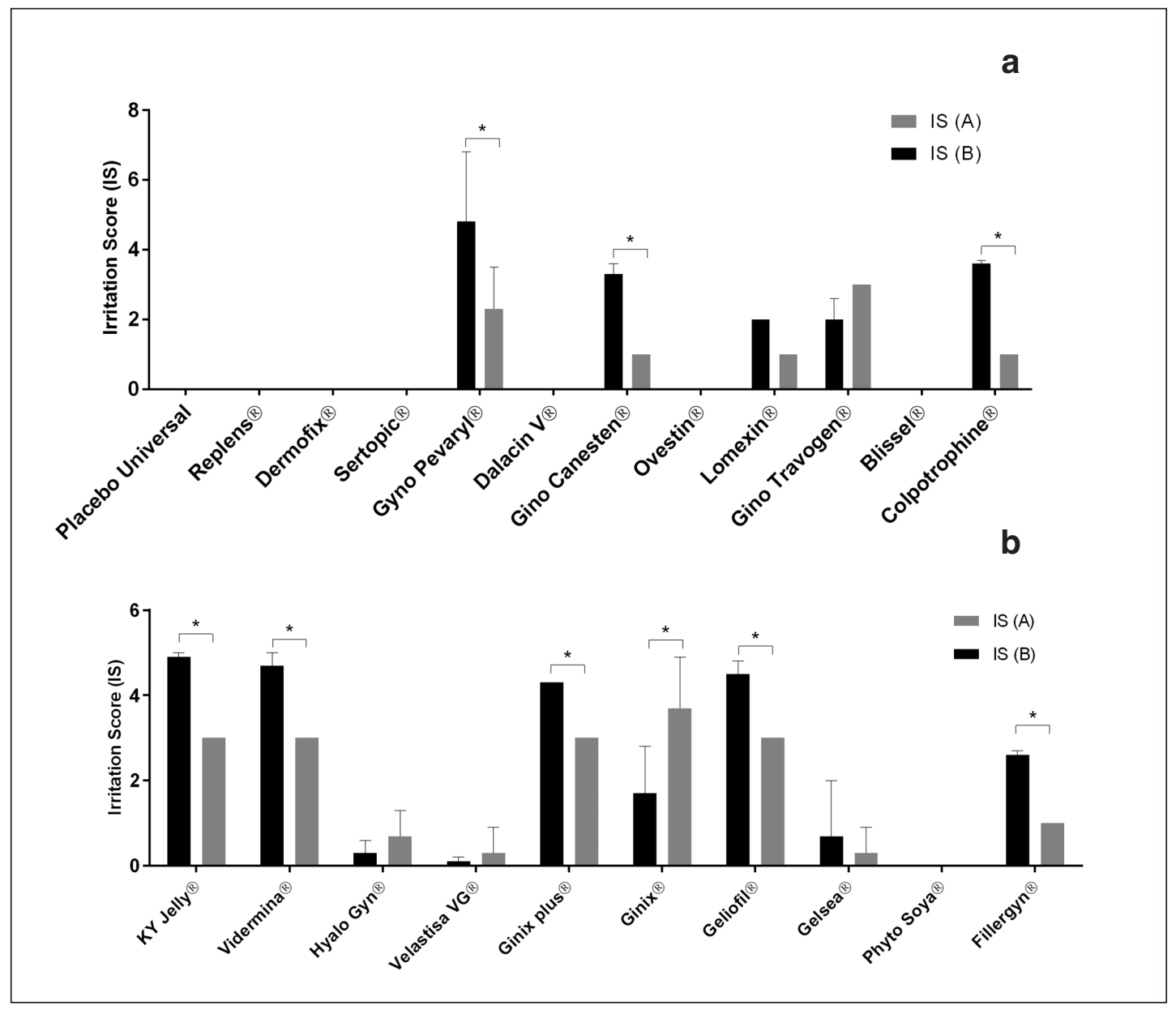

Fig. 2: Irritation scores (IS) for therapeutic vaginal products (a) and vaginal lubricants (b) according to the analysis methods $A$ and $B$ Results are presented as mean values \pm standard deviation (SD), $\mathrm{n}=3 .{ }^{*}, \mathrm{p}<0.05$ (two way-ANOVA, Sidak's multiple comparisons test). 
these scores, these scores are also related with borderline classifications. The two lowest concentrations tested, 0.001 and $0.005 \%$, were regarded as non-irritant and slight irritant, respectively, having scores of $0.9 \pm 0.8$ and $1.1 \pm 1.0$. Using the IS (A) method, a non-severe irritant response was found for concentrations ranging from 0.001 to $1 \%$ with scores of $0.7 \pm 0.6$ to $7.3 \pm 1.2$, respectively. These results show that the most irritant N-9 concentrations are found independent of the method being used. Nonetheless, the IS (B) is able to discriminate the irritation response of a range of N-9 concentrations since it considers more irritation categories compared to IS (A). Interestingly, a reduction in both scores (although more pronounced for IS(A)) against the value of $10 \% \mathrm{~N}-9$ was observed when undiluted N-9 (100\%) was tested. This may be due to a reduction of interactions between the molecules of this non-ionic surfactant and the CAM in the absence of water, consequently reducing the irritant effect in the experimental setup.

The irritation scores determined for the vaginal formulations are represented in Figure 2. The therapeutic products Replens ${ }^{\circledR}$, Dermofix $^{\circledR}$, Sertopic ${ }^{\circledR}$, Dalacin $V^{\circledR}$, Ovestin ${ }^{\circledR}$, and Blissel ${ }^{\circledR}$ as well as the Universal Placebo did not induce any irritant response, being scored with $0 \pm 0$. Gyno Pevaryl ${ }^{\circledR}$, Gino Canesten ${ }^{\circledR}$, and Colpotrophine ${ }^{\circledR}$ had significantly different scores depending on the evaluation method. Using IS (A), they were all classified as non-severe irritants. Using method B, Gino Canesten ${ }^{\circledR}$, Colpotrophine ${ }^{\circledR}$, and Gyno Pevaryl ${ }^{\circledR}$ were classified as slight irritants. All products had higher scores on scale B than on scale A, except Gino Travogen ${ }^{\circledR}$ for which the difference was not statistically significant.

Regarding the vaginal lubricants (Fig. 2b), only Phyto Soya ${ }^{\circledR}$ had a score of zero. Hyalo Gyn ${ }^{\circledR}$, Velastisa VG ${ }^{\circledR}$, and Gelsea ${ }^{\circledR}$, which showed no significant difference when comparing both scales, also obtained the lowest irritant scores on both scales. The remaining products showed significant differences depending on the evaluation method used: All other lubricants were classified as non-severe irritants using the IS (A) irritation criteria, with Ginix ${ }^{\circledR}$ reaching the highest score on this scale $(3.7 \pm 1.2)$, while using IS (B) all others were classified as slight irritants. For all but Ginix $^{\circledR}$, the score obtained on scale B was higher than on A.

Table 2 details the score obtained and the classification attributed to all products tested in this study. Furthermore, a photograph of the last timepoint $(5 \mathrm{~min})$ is shown for products and controls. The IS (B) analysis method allowed to differentiate between non-irritant and slight irritant responses among the tested products although they were all classified as "non-severe irritant" using IS (A). In the case of medicines, Gyno Pevaryl ${ }^{\circledR}$, Gino Canesten ${ }^{\circledR}$, Lomexin ${ }^{\circledR}$, Gino Travogen ${ }^{\circledR}$, and Colpotrophine ${ }^{\circledR}$ were classified as slight irritants using IS (B). Regarding lubricants, KY Jelly ${ }^{\circledR}$, Vidermina ${ }^{\circledR}$, Ginix Plus ${ }^{\circledR}$, Geliofil ${ }^{\circledR}$, and Fillergyn ${ }^{\circledR}$ were classified as slight irritants.

\section{Discussion}

The increasing number of new chemicals and products introduced into the market by the cosmetic, pharmaceutical and medical device industries has generated a need to validate in vitro techniques able to screen potential irritation effects at the early stages of product development. In the vaginal products field, no in vitro organotypic irritation test is currently approved either in the EU or the USA. Some cellular and tissue models are available for toxicity testing, however they mainly comprise techniques for specific metabolic pathways, histological analysis and inflammatory response (Fichorova et al., 2004; Repetto et al., 2008; Gali et al., 2010; Costin et al., 2011). The application of the HET-CAM assay to vaginal irritation testing is therefore in line with the 3 Rs policy.

Our research group is focused on developing strategies for preclinical safety characterization of vaginal products using cellular and ex vivo tissue assays (Machado et al., submitted). The use of the HET-CAM assay for vaginal product testing widens the safety assessment portfolio that can be applied to test substances or products in a faster and more effective way in the first steps of preclinical safety testing.

In this study, several semisolid vaginal medicines and lubricant products were tested. Moreover, two analysis methods for IS calculation were applied and compared. When testing N-9, a pure substance, the two methods yielded comparable scores. The concentration found to be the one that could trigger severe irritant effects, $2 \%(\mathrm{w} / \mathrm{v})$, was the same shown to generate severe toxicity in clinical trials, being less safe than expected from preclinical evaluations (Van Damme et al., 2002). In that case, N-9 was being studied as a spermicide, but, because of its surfactant nature, was shown to be an irritant and even promoted the transmission of HIV infection (Stafford et al., 1998; Phillips et al., 2000; Dayal et al., 2003). Also, data reported from a Draize test with undiluted N-9 indicate that it is severely irritating to the eyes of rabbits ${ }^{2}$. This observation underlines the need for more appropriate in vitro assays to predict in vivo safety issues.

In our study, the surfactant nature of N-9 (U.S. Public Health Service, Department of Health and Human Services, 2006) may explain the fact that further increases of its concentration did not result in a higher rate of irritation. Instead, the irritation score decreased when the undiluted substance was tested in comparison to other dilutions above $2 \%$. As most tests are performed with undiluted substances to assess their worst possible effect, it should be considered that in addition some degree of dilution may be important (especially when the substance is intended to be used in diluted form) so that the response in the (dry) CAM may be similar to that observed in situ.

Universal Placebo was included as a vaginal gel designed as a control formulation for clinical trials of vaginal microbicides (Tien et al., 2005; Schwartz et al., 2007). Its safety profile, already confirmed by clinical trials, was also confirmed in this study with an IS of zero on both scoring grids (A and B).

Concerning semisolid vaginal medicines, no severe irritant responses were observed as expected. The formulations are already commercialized and since they are classified as medicines, they were not only subjected to preclinical evaluations, but also to extensive clinical trials. In the products' available literature (Summary of Product Characteristics) provided by Pharmaceutical Companies to Health Professionals, all of these vaginal

\footnotetext{
2 https://online.personalcarecouncil.org/ctfa-static/online/lists/cir-pdfs/FR695.pdf (accessed 23.12.2017)
} 
Tab. 2: Irritation potential

Irritation scores, IS (A) and (B) determined for vaginal semisolid medicines and lubricants.

\begin{tabular}{|c|c|c|c|c|c|}
\hline \multicolumn{3}{|l|}{ Medicines } & \multicolumn{3}{|l|}{ Lubricants } \\
\hline Product & IS (A) & IS (B) & Product & IS (A) & IS (B) \\
\hline Placebo Universal & $\begin{array}{l}\text { Non-severe } \\
\text { irritant }(0)\end{array}$ & Non-irritant (0) & KY Jelly ${ }^{\circledR}$ & $\begin{array}{l}\text { Non-severe } \\
\text { irritant (3) }\end{array}$ & $\begin{array}{l}\text { Slight } \\
\text { irritant (4.9) }\end{array}$ \\
\hline Replens $^{\circledR}$ & $\begin{array}{l}\text { Non-severe } \\
\text { irritant (0) }\end{array}$ & Non-irritant (0) & Vidermina ${ }^{\circledR}$ & $\begin{array}{l}\text { Non-severe } \\
\text { irritant (3) }\end{array}$ & $\begin{array}{l}\text { Slight } \\
\text { irritant (4.7) }\end{array}$ \\
\hline Dermofix $^{\circledR}$ & $\begin{array}{l}\text { Non-severe } \\
\text { irritant }(0)\end{array}$ & Non-irritant (0) & Hyalo Gyn ${ }^{\circledR}$ & $\begin{array}{l}\text { Non-severe } \\
\text { irritant (0.7) }\end{array}$ & $\begin{array}{l}\text { Non- } \\
\text { irritant }(0.3)\end{array}$ \\
\hline Sertopic ${ }^{\circledR}$ & $\begin{array}{l}\text { Non-severe } \\
\text { irritant }(0)\end{array}$ & Non-irritant (0) & Velastisa VG ${ }^{\circledR}$ & $\begin{array}{l}\text { Non-severe } \\
\text { irritant (0.3) }\end{array}$ & $\begin{array}{l}\text { Non- } \\
\text { irritant }(0.1)\end{array}$ \\
\hline Gyno Pevaryl ${ }^{\circledR}$ & $\begin{array}{l}\text { Non-severe } \\
\text { irritant (2.3) }\end{array}$ & $\begin{array}{l}\text { Slight } \\
\text { irritant (4.8) }\end{array}$ & Ginix plus ${ }^{\circledR}$ & $\begin{array}{l}\text { Non-severe } \\
\text { irritant (3) }\end{array}$ & $\begin{array}{l}\text { Slight } \\
\text { irritant (4.3) }\end{array}$ \\
\hline Dalacin $\mathrm{V}^{\circledR}$ & $\begin{array}{l}\text { Non-severe } \\
\text { irritant }(0)\end{array}$ & Non-irritant (0) & $\operatorname{Ginix}^{\circledR}$ & $\begin{array}{l}\text { Non-severe } \\
\text { irritant (3.7) }\end{array}$ & $\begin{array}{l}\text { Slight } \\
\text { irritant (1.7) }\end{array}$ \\
\hline Gino Canesten ${ }^{\circledR}$ & $\begin{array}{l}\text { Non-severe } \\
\text { irritant (1) }\end{array}$ & $\begin{array}{l}\text { Slight } \\
\text { irritant (3.3) }\end{array}$ & Geliofil $^{\circledR}$ & $\begin{array}{l}\text { Non-severe } \\
\text { irritant (3) }\end{array}$ & $\begin{array}{l}\text { Slight } \\
\text { irritant (4.5) }\end{array}$ \\
\hline Ovestin $^{\circledR}$ & $\begin{array}{l}\text { Non-severe } \\
\text { irritant }(0)\end{array}$ & Non-irritant (0) & Gelsea $^{\circledR}$ & $\begin{array}{l}\text { Non-severe } \\
\text { irritant }(0.3)\end{array}$ & $\begin{array}{l}\text { Slight } \\
\text { irritant (0.7) }\end{array}$ \\
\hline Lomexin ${ }^{\circledR}$ & $\begin{array}{l}\text { Non-severe } \\
\text { irritant (1) }\end{array}$ & $\begin{array}{l}\text { Slight } \\
\text { irritant (2) }\end{array}$ & Phyto soya ${ }^{\circledR}$ & $\begin{array}{l}\text { Non-severe } \\
\text { irritant (0) }\end{array}$ & $\begin{array}{l}\text { Slight } \\
\text { irritant (0) }\end{array}$ \\
\hline Gino Travogen ${ }^{\circledR}$ & $\begin{array}{l}\text { Non-severe } \\
\text { irritant (2) }\end{array}$ & $\begin{array}{l}\text { Slight } \\
\text { irritant (3) }\end{array}$ & Fillergyn ${ }^{\circledR}$ & $\begin{array}{l}\text { Non-severe } \\
\text { irritant (1) }\end{array}$ & $\begin{array}{l}\text { Slight } \\
\text { irritant (2.6) }\end{array}$ \\
\hline Blisse $\mathrm{I}^{\circledR}$ & $\begin{array}{l}\text { Non-severe } \\
\text { irritant (0) }\end{array}$ & Non-irritant (0) & & & \\
\hline Colpotrophine $^{\circledR}$ & $\begin{array}{l}\text { Non-severe } \\
\text { irritant (1) }\end{array}$ & $\begin{array}{l}\text { Slight } \\
\text { irritant (3.6) }\end{array}$ & & & \\
\hline \multicolumn{6}{|l|}{ Assay controls } \\
\hline Product & IS (A) & IS (B) & Product & IS (A) & IS (B) \\
\hline $\begin{array}{l}\mathrm{N}-92 \%(\mathrm{v} / \mathrm{v}) \\
\text { (Positive control) }\end{array}$ & $\begin{array}{l}\text { Severe } \\
\text { irritant (10) }\end{array}$ & $\begin{array}{l}\text { Severe } \\
\text { irritant (10.8) }\end{array}$ & $\begin{array}{l}\mathrm{NaOH} 0.1 \mathrm{~N} \\
\text { (Positive control) }\end{array}$ & $\begin{array}{l}\text { Severe } \\
\text { irritant (19) }\end{array}$ & $\begin{array}{l}\text { Severe } \\
\text { irritant (19) }\end{array}$ \\
\hline $\begin{array}{l}\text { SDS 1\% (w/v) } \\
\text { (Positive control) }\end{array}$ & $\begin{array}{l}\text { Severe } \\
\text { irritant (10) }\end{array}$ & $\begin{array}{l}\text { Severe } \\
\text { irritant (10) }\end{array}$ & $\begin{array}{l}\mathrm{NaCl} 0.9 \%(\mathrm{w} / \mathrm{v}) \\
\text { (Negative control) }\end{array}$ & $\begin{array}{l}\text { Non-severe } \\
\text { irritant (0) }\end{array}$ & $\begin{array}{l}\text { Non-severe } \\
\text { irritant (0) }\end{array}$ \\
\hline
\end{tabular}


products have been associated with adverse effects related to irritancy in clinical trials or post-marketing surveillance, however, the frequency reported for these effects is generally either rare or unknown. The in vivo impact of the result "slight irritation" of the lubricants according to IS (B) is not known since, to our knowledge, clinical data referring to the adverse effects are not generally available.

Moreover, the products classified here as non-severe irritants (IS (A)) and slight to moderate irritants (IS (B)), such as Gyno Pevaryl ${ }^{\circledR}$, Gino Canesten ${ }^{\circledR}$, Colpotrophine ${ }^{\circledR}$, Gino Travogen ${ }^{\circledR}$, and Lomexin ${ }^{\circledR}$ were also tested by our research group using two in vitro cytotoxicity tests: 3-(4,5-dimethylthiazol-2-yl)-2,5-diphenyltetrazolium bromide (MTT) and neutral red uptake (NRU) in uterine (HEC-1A), cervical (HeLa) and vaginal (VK2 E6/E7) cell lines, and on an ex vivo porcine vaginal model using the MTT reduction assay and histological analysis. The cellular viability (MTT and NRU) tests demonstrated toxicity profiles higher than the controls which can be due to the drug and/or excipients of these products. In fact, besides demonstrating a cytotoxic profile, Gino Canesten ${ }^{\circledR}$ also had a major impact on the vaginal ex vivo epithelia as demonstrated by histological analysis. Furthermore, Gino Travogen ${ }^{\circledR}$ and Colpotrophine ${ }^{\circledR}$ presented high toxicities in the ex vivo model developed by our research group (Machado et al., submitted). In a previous study by our research group in 2014, vaginal lubricants Ginix ${ }^{\circledR}$ and Ginix Plus ${ }^{\circledR}$ had already shown higher toxic profiles on HeLa cervical cells using the lactate dehydrogenase (LDH) colorimetric cytotoxicity assay (Cunha et al., 2014). K-Y ${ }^{\circledR}$ Jelly and Ginix Plus ${ }^{\circledR}$, that are herein considered HET-CAM borderline products, had previously demonstrated higher cytotoxicities (Cunha et al., 2014). Having this and our cytotoxicity results in mind, it was also herein demonstrated that these products could be considered borderline products, as some degree of irritancy was revealed by the IS (B) method. These results, however, do not mean that these products are not adequate for the purpose of use since it should be kept in mind that most of the drug products are prescribed for short term use and this factor is obviously important for their benefit/risk assessment. This data congruency might corroborate the need to perform several in vitro tests for a complete toxicity evaluation, since the combined results might be stronger predictors for in vivo toxicity (Samuel et al., 2016).

Furthermore, osmolality has been shown to be associated with the safety of vaginal products (Adriaens and Remon, 2008). Our research group has previously reported osmolality results for the medicinal products and lubricants tested herein (Machado et al., 2017) and found that some that showed higher IS in the HET-CAM assay were also highly hyperosmolal, i.e., Lomexin ${ }^{\circledR}$ (1446 $\pm 20 \mathrm{mOsmol} / \mathrm{kg})$, Colpothrophine ${ }^{\circledR}(1723 \pm 20 \mathrm{mOsmol} / \mathrm{kg})$, Geliofil $^{\circledR}(3582 \pm 11 \mathrm{mOsmol} / \mathrm{kg})$, Vidermina ${ }^{\circledR}(3707 \pm 16$ mOs$\mathrm{mol} / \mathrm{kg})$, and $\mathrm{K}-\mathrm{Y}^{\circledR}$ Jelly $(3631 \pm 13 \mathrm{mOsmol} / \mathrm{kg})$ were highly hyperosmolal, all above the upper limit recommended by the WHO (1200 mOsmol/kg) (WHO, 2012; Machado et al., 2017).

Together, these findings strengthen the hypothesis that product osmolality and cellular and tissue toxicity could be highly predictive of irritation potential and suggest that these techniques (HET-CAM, osmolality, cell/tissue metabolic toxicity) should be applied concomitantly for a more robust clinical irritation response prediction.

The application of the two scoring analysis methods, IS (A) and (B), confirmed that IS (B), although being more difficult to perform and also requiring a more qualified operator, can lead to a more detailed classification output. Also, it generally leads to a higher IS, which means that it could be scoring false positive irritants, rather than false negatives. From a safety perspective, this should be regarded as more valuable in comparison to IS (A), being especially important for screening prototypes during product development processes. Nevertheless, it is important to note that the current ICCVAM protocol suggests the use of IS (A) in prospective studies and the conversion of IS (B) to IS(A) regarding retrospective studies. This recommendation is based on the fact that, according to the currently available data, the purpose of this test method is to detect severe ocular irritants and not to differentiate the range of irritancy potential among products.

The suitability of the HET-CAM assay for vaginal irritation testing was demonstrated with this study, although further assays and controls as well as inter-laboratory testing to confirm its reproducibility are needed to complete the validation process. Additionally, the improvements that were tested in the past for the HET-CAM applied to testing cosmetic ingredients' eye toxicity, like an additional histological analysis (Djabari et al., 2002) and the combination of two softwares (Image ${ }^{\circledR}$ and Adobe Photoshop $\left.{ }^{\circledR}\right)$, which allows live monitoring of the assay, reducing the subjectivity of the endpoint evaluation (McKenzie et al., 2015), shall be considered in this approach in order to assure more accurate results.

Until now no single in vitro test has emerged as being completely acceptable for full replacement of in vivo tests. However, the HET-CAM has gained regulatory acceptance in various countries to classify severe eye irritants, and has potential to be applied to other mucosal/epithelial substrates such as the vaginal epithelia.

\section{Conclusions}

The HET-CAM assay was transposed and applied to vaginal irritation testing. This strategy represents an innovative approach for the preclinical safety assessment of vaginal products classified as medicines, cosmetics, hygiene products or medical devices. The comparison of the two scoring methods, IS (A) and (B), confirmed that IS (B) can conduct a more detailed classification output and should be preferable for this purpose, provided that this sensitivity is supported by in vivo studies. The studied vaginal formulations, comprising medicines and lubricants, showed, as expected, low potential for irritation. N-9 was considered a severe irritant above $2 \%(\mathrm{v} / \mathrm{v})$ concentrations, which is in line with clinical data from the literature, envisaging a possible in vitro/in vivo correlation. Comparisons with previous studies by our group confirmed that HET-CAM can predict and/or confirm toxic profiles for products also tested for osmolality and cellular/ tissue toxicity. Ideally, an integrative methodology should be designed to embrace all these preclinical tests for a better in vivo 
safety prediction. Although still requiring further validation, the HET-CAM assay seems an ideal prospect for vaginal irritancy potential in vitro studies.

\section{References}

Acartürk, F. (2009). Mucoadhesive vaginal drug delivery systems. Recent Pat Drug Deliv Formul 3, 193-205. doi:10.2174/187221109789105658

Adriaens, E. and Remon, J. P. (2008). Mucosal irritation potential of personal lubricants relates to product osmolality as detected by the slug mucosal irritation assay. Sex Transm Dis 35, 512-516. doi:10.1097/OLQ.0b013e3181644669

Alexander, N. J., Baker, E., Kaptein, M. et al. (2004). Why consider vaginal drug administration? Fertil Steril 82, 1-12. doi:10.1016/j.fertnstert.2004.01.025

Batista-Duharte, A., Jorge Murillo, G., Pérez, U. M. et al. (2016). The hen's egg test on chorioallantoic membrane. Int J Toxicol 35, 627-633. doi:10.1177/1091581816672187

Bender, C., Partecke, L.-I., Kindel, E. et al. (2011). The modified HET-CAM as a model for the assessment of the inflammatory response to tissue tolerable plasma. Toxicol In Vitro 25, 530537. doi:10.1016/j.tiv.2010.11.012

Borges, J., Tegtmeier, F. T., Padron, N. T. et al. (2003) Chorioallantoic membrane angiogenesis model for tissue engineering: A new twist on a classic model. Tissue Eng 9, 441-450. doi:10.1089/107632703322066624

Bygdeman, M. and Swahn, M. L. (1996). Replens versus dienoestrol cream in the symptomatic treatment of vaginal atrophy in postmenopausal women. Maturitas 23, 259-263. doi:10.1016/0378-5122(95)00955-8

Caramella, C. M., Rossi, S., Ferrari, F. et al. (2015). Mucoadhesive and thermogelling systems for vaginal drug delivery. $A d v$ Drug Deliv Rev 92, 39-52. doi:10.1016/j.addr.2015.02.001

Choudhury, A., Das, S. and Kar, M. (2011). A review on novelty and potentiality of vaginal drug delivery. Int J PharmTech Res 3, 1033-1044.

Clark, M. R., McCormick, T. J., Doncel, G. F. et al. (2011). Preclinical evaluation of UC781 microbicide vaginal drug delivery. Drug Deliv and Transl Res 1, 175-182. doi:10.1007/ s13346-011-0019-1

Costin, G., Raabe, H. and Priston, R. (2011). Vaginal irritation models: The current status of available alternative and in vitro tests. Altern Lab Anim 39, 317-337.

Cunha, A. R., Machado, R. M., Palmeira-de-Oliveira, A. et al. (2014). Characterization of commercially available vaginal lubricants: A safety perspective. Pharmaceutics 6, 530-542. doi:10.3390/pharmaceutics6030530

Dahl, J. E. (2007). Potential of dental adhesives to induce mucosal irritation evaluated by the HET-CAM method. Acta Odontol Scand 65, 275-283. doi:10.1080/00016350701589286

Dayal, M. B., Wheeler, J., Williams, C. J. et al. (2003). Disruption of the upper female reproductive tract epithelium by nonoxynol-9. Contraception 68, 273-279. doi:10.1016/ S0010-7824(03)00178-1

Djabari, Z., Bauza, E., Dal Farra, C. et al. (2002). The HET-CAM test combined with histological studies for better evaluation of active ingredient innocuity. Int J Tissue React 24, 117-121.

Eckstein, P., Jackson, M. C., Millman, N. et al. (1969). Comparison of vaginal tolerance tests of spermicidal preparations in rabbits and monkeys. $J$ Reprod Fertil 20, 85-93. doi:10.1530/ jrf.0.0200085

EC - European Commission (2003). Regulation (EC) of No 2003/15 of the European parliament and of the council 27 February 2003 concerning the $7^{\text {th }}$ Amendment to the Cosmetics Directive.

Fernández-Ferreiro, A., González Barcia, M., Gil Martínez, M. et al. (2014). Análisis de la toxicidad ocular de los colirios de voriconazol y fluconazol con HET-CAM (Analysis of ocular toxicity of fluconazole and voriconazole eyedrops using HET CAM). Farm Hosp 38, 300-304. doi:10.7399/ FH.2014.38.4.7343

Fichorova, R. N., Bajpai, M., Chandra, N. et al. (2004). Interleukin (IL)-1, IL-6, and IL-8 predict mucosal toxicity of vaginal microbicidal contraceptives. Biol Reprod 71, 761-769. doi:10.1095/biolreprod.104.029603

Gali, Y., Delezay, O., Brouwers, J. et al. (2010). In vitro evaluation of viability, integrity, and inflammation in genital epithelia upon exposure to pharmaceutical excipients and candidate microbicides. Antimicrob Agents Chemother 54, 5105-5114. doi:10.1128/AAC.00456-10

Garg, S., Anderson, R. A., Chany, C. J. et al. (2001). Properties of a new acid-buffering bioadhesive vaginal formulation (ACIDFORM). Contraception 64, 67-75. doi:10.1016/S00107824(01)00217-7

Garg, S., Goldman, D., Krumme, M. et al. (2010). Advances in development, scale-up and manufacturing of microbicide gels, films, and tablets. Antiviral Res 88, Suppl 1, S19-S29. doi:10.1016/j.antiviral.2010.09.010

Hussain, A. and Ahsan, F. (2005). The vagina as a route for systemic drug delivery. J Control Release 103, 301-313. doi:10.1007/s00192-012-2009-3

ICCVAM (2007). Guidance Document - ESAC Peer Review. Organotypic in vitro assays to identify severe eye irritants - ICCVAM-NICEATM Retrospective Evaluation. https://eurl-ecvam.jrc.ec.europa.eu/validation-regulatory-acceptance/ docs-eye-irritation/Annex I. Guidance document_ESAC PRP Organotypics-finalcleared.pdf (accessed 23.08.2017).

ISO 10993-10 (2010). International Standard. Biological evaluation of medical devices - Part 10: Tests for irritation and skin sensitization. https://www.iso.org/standard/40884.html

Leontaridou, M., Urbisch, D., Kolle, S. N. et al. (2017). The borderline range of toxicological methods: Quantification and implications for evaluating precision. ALTEX 34, 525-538. doi:10.14573/altex.1606271

Liebsch, M., Grune, B., Seiler, A. et al. (2011). Alternatives to animal testing: Current status and future perspectives. Arch Toxicol 85, 841-858. doi:10.1007/s00204-011-0718-x

Lönnroth, E. C., Dahl, J. and Shahnavaz, H. (1999). Evaluating the potential occupational hazard of handling dental polymer products using the HET-CAM technique. Int J Occup Saf Ergon 5, 43-57. doi:10.1080/10803548.1999.11076410 
Luepke, N. P. (1985). Hen's egg chorioallantoic membrane test for irritation potential. Food Chem Toxicol 23, 287-291. doi:10.1016/0278-6915(85)90030-4

Machado, R. M., Palmeira-de-Oliveira, A., Martinez-de-Oliveira, J. and Palmeira-de-Oliveira, R. (2017). Vaginal semisolid products: Technological performance considering physiologic parameters. Eur J Pharm Sci 109, 556-568. doi:10.1016/j. ejps.2017.09.009

Machado, R. M., Palmeira-de-Oliveira, A., Breitenfeld, L., Martinez-de-Oliveira, J. and Palmeira-de-Oliveira, R. Optimization and application of in vitro and ex vivo models for vaginal semisolids safety evaluation. (submitted for publication).

Marquardt, C., Matuschek, E., Bölke, E. et al. (2010). Evaluation of the tissue toxicity of antiseptics by the hen's egg test on the chorioallantoic membrane (HETCAM). Eur J Med Res 15, 204-209. doi:10.1186/2047-783X-15-5-204

McKenzie, B., Kay, G., Matthews, K. H. et al. (2015). The hen's egg chorioallantoic membrane (HET-CAM) test to predict the ophthalmic irritation potential of a cysteamine-containing gel: Quantification using Photoshop ${ }^{\circledR}$ and ImageJ. Int J Pharm 490, 1-8. doi:10.1016/j.ijpharm.2015.05.023

Nachtigall, L. E. (1994). Comparative study: Replens versus local estrogen in menopausal women. Fertil Steril 61, 178-180. doi:10.1016/S0015-0282(16)56474-7

OECD - Organisation for Economic Co-operation and Development (2012). OECD Test Guideline 405: Acute Eye Irritation/ Corrosion. doi:10.1787/9789264185333-en

Phillips, D. M., Taylor, C. L., Zacharopoulos, V. R. et al. (2000). Nonoxynol-9 causes rapid exfoliation of sheets of rectal epithelium. Contraception 62, 149-154. doi:10.1016/S00107824(00)00156-6

Repetto, G., del Peso, A. and Zurita, J. L. (2008). Neutral red uptake assay for the estimation of cell viability/cytotoxicity. Nat Protoc 3, 1125-1131. doi:10.1038/nprot.2008.75

Samuel, G. O., Hoffmann, S., Wright, S. A. et al. (2016). Guidance on assessing the methodological and reporting quality of toxicologically relevant studies: A scoping review. Environ Int 92, 630-646. doi:10.1016/j.envint.2016.03.010

Schwartz, J. L., Ballagh, S. A., Kwok, C. et al. (2007). Fourteen-day safety and acceptability study of the universal placebo gel. Contraception 75, 136-141. doi:10.1016/j.contraception. 2006.09.003

Spielmann, H. (1992). HET-CAM Test. The ERGATT/FRAME Databank of in vitro techniques (INVITTOX) 1-9.

Spielmann, H. (1995). HET-CAM Test. In S. O’Hare and C. K. Atterwill (eds), In Vitro Toxicity Testing Protocols (199-204). Methods in Molecular Biology ${ }^{\mathrm{TM}}$, Volume 43. Humana Press. doi:10.1385/0-89603-282-5:199

Stafford, M. K., Ward, H., Flanagan, A. et al. (1998). Safety study of nonoxynol-9 as a vaginal microbicide: Evidence of adverse effects. J Acquir Immune Defic Syndr Hum Retrovirol 17, 327-331. doi:10.1097/00042560-199804010-00006
Steiling, W., Bracher, M., Courtellemont, P. and de Silva, O. (1999). The HET-CAM, a useful in vitro assay for assessing the eye irritation properties of cosmetic formulations and ingredients. Toxicol In Vitro 13, 375-384. doi:10.1016/S08872333(98)00091-5

Tien, D., Schnaare, R. L., Kang, F. et al. (2005). In vitro and in vivo characterization of a potential universal placebo designed for use in vaginal microbicide clinical trials. AIDS Res Hum Retroviruses 21, 845-853. doi:10.1089/aid.2005.21.845

U.S. Public Health Service, Department of Health and Human Services (2006). Current Status of In Vitro Test Methods for Identifying Ocular Corrosives and Severe Irritants: Hen's Egg Test - Chorioallantoic Membrane Test Method. NIH Publication No: 06-4515.

Valenta, C. (2005). The use of mucoadhesive polymers in vaginal delivery. Adv Drug Deliv Rev 57, 1692-1712. doi:10.1016/j. addr.2005.07.004

Van Damme, L., Ramjee, G., Alary, M. et al. (2002). Effectiveness of COL-1492, a nonoxynol-9 vaginal gel, on HIV-1 transmission in female sex workers: A randomised controlled trial. Lancet 360, 971-977. doi:10.1016/S0140-6736(02)11079-8

Vargas, A., Zeisserlabouebe, M., Lange, N. et al. (2007) The chick embryo and its chorioallantoic membrane (CAM) for the in vivo evaluation of drug delivery systems. Adv Drug Deliv Rev 59, 1162-1176. doi:10.1016/j.addr.2007.04.019

Woolfson, A. D., Malcolm, R. K. and Gallagher, R. (2000). Drug delivery by the intravaginal route. Crit Rev Ther Drug Carrier Syst 17, 509-555. doi:10.1615/CritRevTherDrugCarrierSyst. v17.i5.30

WHO - World Health Organization (2012). Use and procurement of additional lubricants for male and female condoms: WHO/UNFPA/FHI360 Advisory note. http://apps.who.int/ iris/bitstream/10665/76580/1/WHO_RHR_12.33_eng.pdf

\section{Conflict of interest}

The authors declare that they have no conflicts of interest.

\section{Acknowledgements}

This work was supported by FEDER funds through the POCI - COMPETE 2020 - Operational Programme Competitiveness and Internationalisation in Axis I - Strengthening research, technological development and innovation (Project POCI-01-0145FEDER-007491) and National Funds by FCT - Foundation for Science and Technology (Project UID/Multi/00709/2013). Financial support was also provided by Labfit, HPRD, Lda. and FCT - Foundation for Science and Technology through a PhD fellowship (Grant Reference SFRH/BDE/111544/2015). Rita Palmeira de Oliveira acknowledges FCT for a Post-Doctoral fellowship (Reference SFRH/BPD/124437/2016). 